
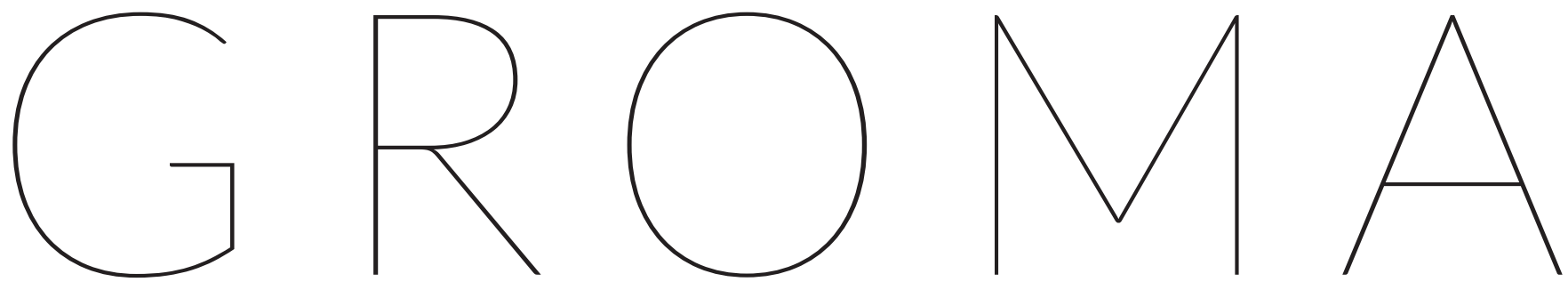

documenting archaeology | dept. of history and cultures, university of bologna

Open-Access E-Journal about methodology applied to archaeology http://groma.unibo.it

Nora Lucentini, Serena De Cesare, Michele Massoni

The Digs in the Upper town of San Benedetto

Del Tronto (2010-2014)

Volume 2-2017

ISSN: $1825-411 X$

pp. 1-V

DOI: $10.12977 / g r o m a 11$

Publisher: BraDypUS [http://books.bradypus.net]

Publication date: 03/11/2017

License: CC BY-NC-ND 4.0 International

Section: Notes 


\section{The Digs in the Upper town of San Benedetto Del Tronto (2010-2014)}

The safety and redevelopment works on the Upper Town of San Benedetto del Tronto, carried out between 2010 and 2014, allowed for the discovery of an interesting slice of life of the city during the Roman and medieval period. Even if it is still being studied, these discoveries have given the city its millennial history back which has its roots right in the Roman era.

In Piazza Sacconi, inside the former Sciarra School and in Via dei Neroni, between the foundation walls of the medieval town, bits of mosaic flooring and of plastered walls of a rich Roman domus dating back to the beginning of the 1 st century $\mathrm{BC}$ emerged. One of the areas has a mosaic in opus scutulatum with colored stones on the inside of a black frame and a threshold on which a resting animal is depicted. The building, which towards the south had a colonnade perhaps as part of a peristyle, seems to have occupied at least all of the southeastern part of the hill of the Upper Town, running down the slope towards the south, parallel to the current Via Rossini, while towards the west, the medieval town destroyed every trace of the Roman phase.

The use of the rooms towards the north is different, in Piazza Sacconi and in Piazza Bice Piacentini. Rooms emerged that were paved with opus signinum or in opus spicatum, in which case the floorings were applied one on top of the other, a sign of later refinishing; and then washing tubs covered in hydraulic opus signinum, draining floors of amphorae and probably a storage area organized with big, buried dolia, found in the 1800s under the current Palazzo Nero-

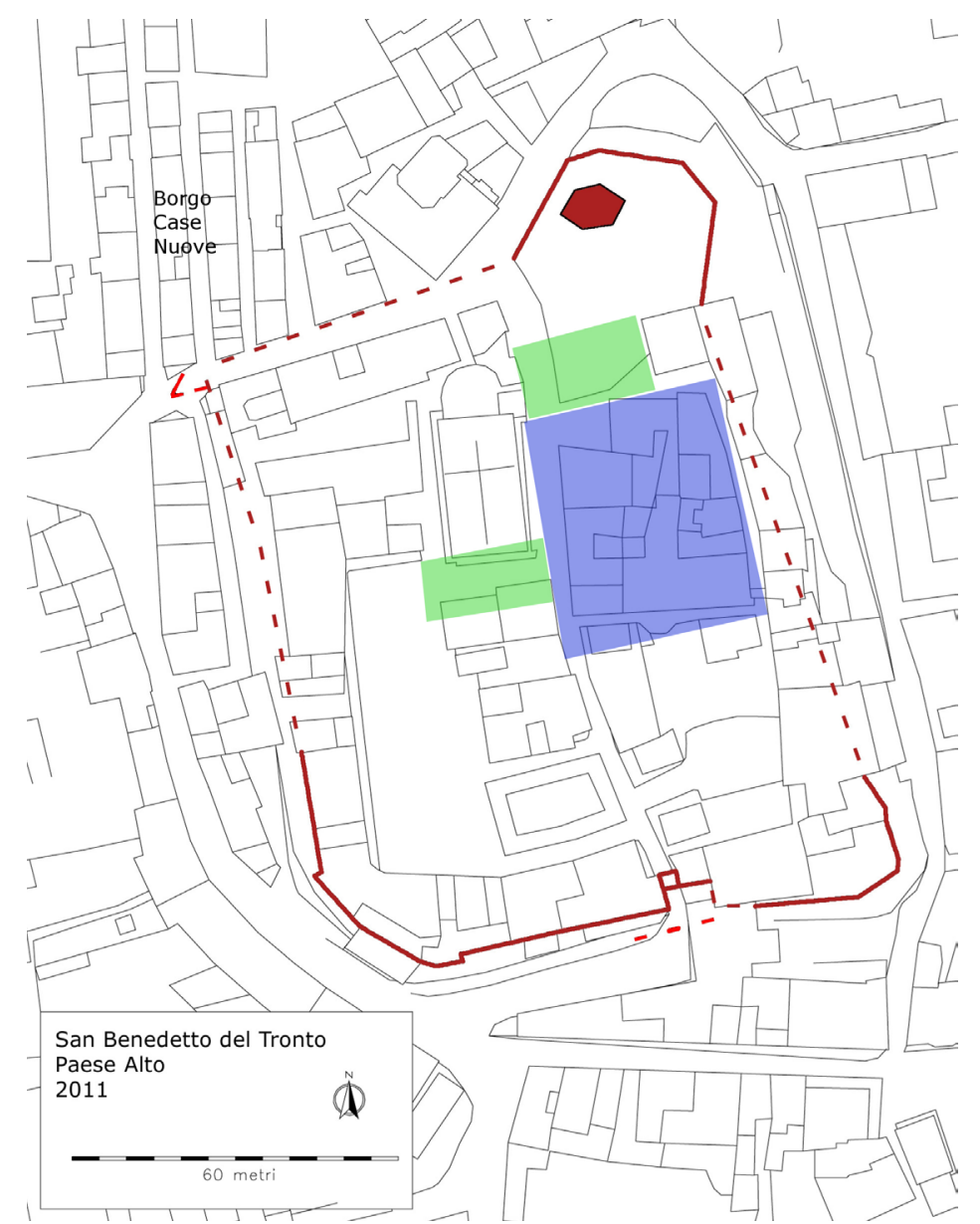

Fig. 1. Planimetry of the Upper Town of San Benedetto Del Tronto. The probable extension of the rich Roman domus (in blue) and of the production areas (in green). In red, the walls of the medieval castle. 


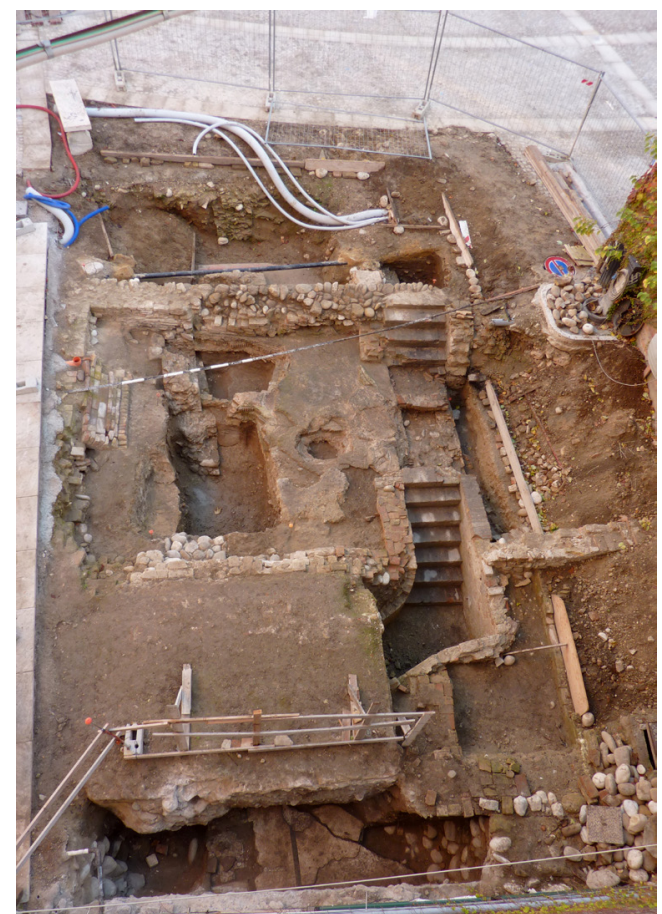

Fig. 2. General view of external excavations.

ni. These rooms, traceable to a production plant or a place where raw materials were worked on, could be from the same era as the domus, but some floorings in opus signinum and spicatum go beyond the walls of the areas where guests were hosted, so the idea that part of this rich home was transformed in its use cannot be excluded.

The underground tunnel, still visible today under Palazzo Bice Piacentini, discovered halfway through the 1800 s, has a vault made out of pieces of amphora and the draining walls include a row of amphora necks reused as building elements. Tunnels and underground passages are common in Roman constructions as passageways: in this case, maybe the villa was linked to a river landing along the Albula. Ancient populations in fact, when there was not a natural port in the mid Adriatic region, essentially used inlets within the river mouths.

Life at the villa continued for a long time, about half a millennium. Of its final phase, in the 4th century $\mathrm{AD}$, we are familiar with some burials that reuse tubs and walls that had already been abandoned. Among the burials recently discovered, one deserves

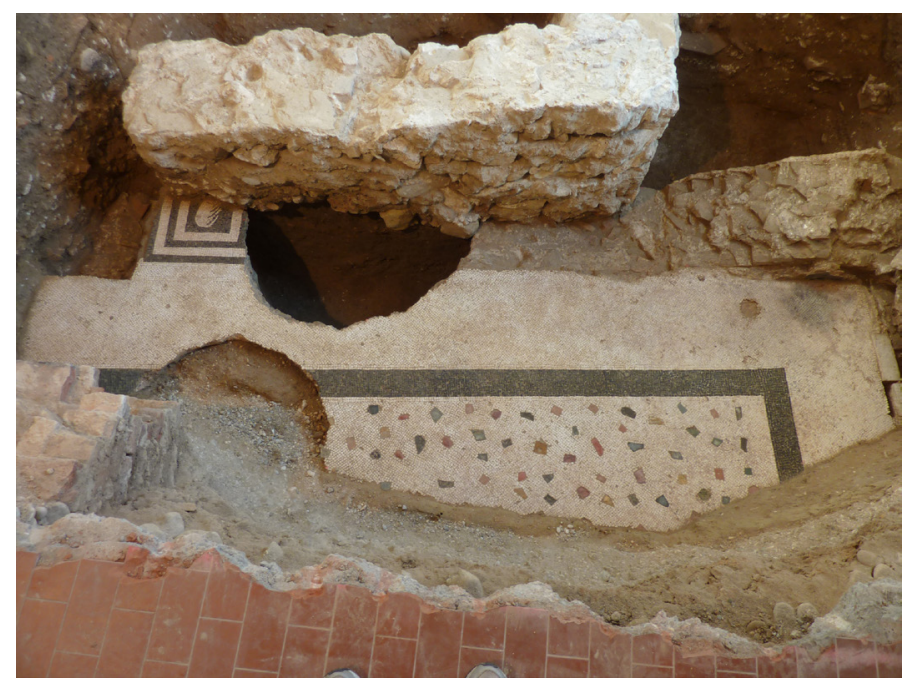

Fig. 3. Mosaic in opus scutulatum.

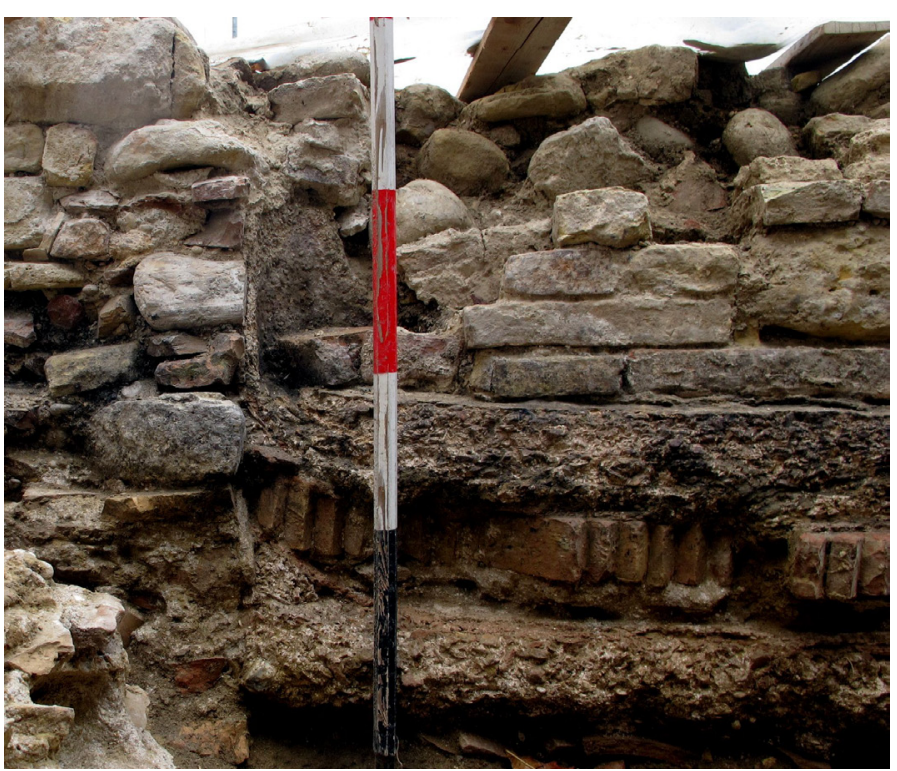

Fig. 4. Section with floorings in opus signinum and spicatum, applied one on top of the other.

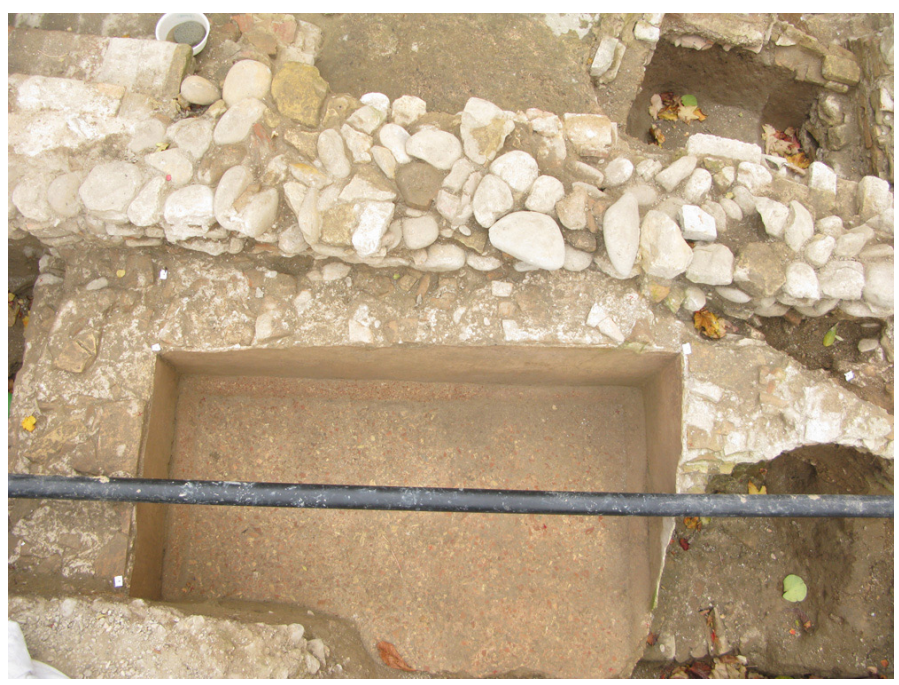

Fig. 5. Washing tub covered in hydraulic opus signinum. 
particular attention: it is a double burial, with two bodies placed side by side inside one of the tubs of the villa, exactly as tradition describes the burial of the remains of the martyr Benedict, buried together with his sister Fructa. In 1842 in fact, an archeological dig was done in the southeast corner of the church to try to identify the legendary tomb of the martyr that Cardinal Lambertini considered "a certain Saint, but of an uncertain name" (referring to a relic dug up in the catacombs of Rome, baptized with a convenient name and "exported" as an object of worship). After more than 150 years, these digs instead show that it was a local burial which became at a certain point (we do not know when or why) a cult object.

The recent data acquired instead does not allow us to say yet if today's San Benedetto dates back to the 1st century BC without any continuous settlements thereafter or if, after a long abandonment between late antiquity and the early Middle Ages a religious establishment, the Sancto Benedicto ad Albulam, cited in sources around the year 1000, became a town and then a parish in which the remains of the martyr in the double burial tomb were venerated.

The finds discovered from the medieval era are much clearer and higher in number: in Via Voltattorni important structures have emerged that can be traced back to the first walls of the castle that, based on what has been passed down to us in terms of the precious information contained in the archival sources, results as being built around a parish in the year 1146 by Berardo and Attone, sons of Gualtiero da Napoli, under a concession made by the bishop of Fermo Liberto. The walls that are still visible today are the result of at least two main construction interventions that included first the building of the walls and then the addition of a support shoe, a technique introduced only after the second half of the 15th century, to combat the shooting of firearms. From the examination of the walls found in the digs, there is not a support, and also the archival sources tell us that this was added between 1400 and 1500 under an ordinance by

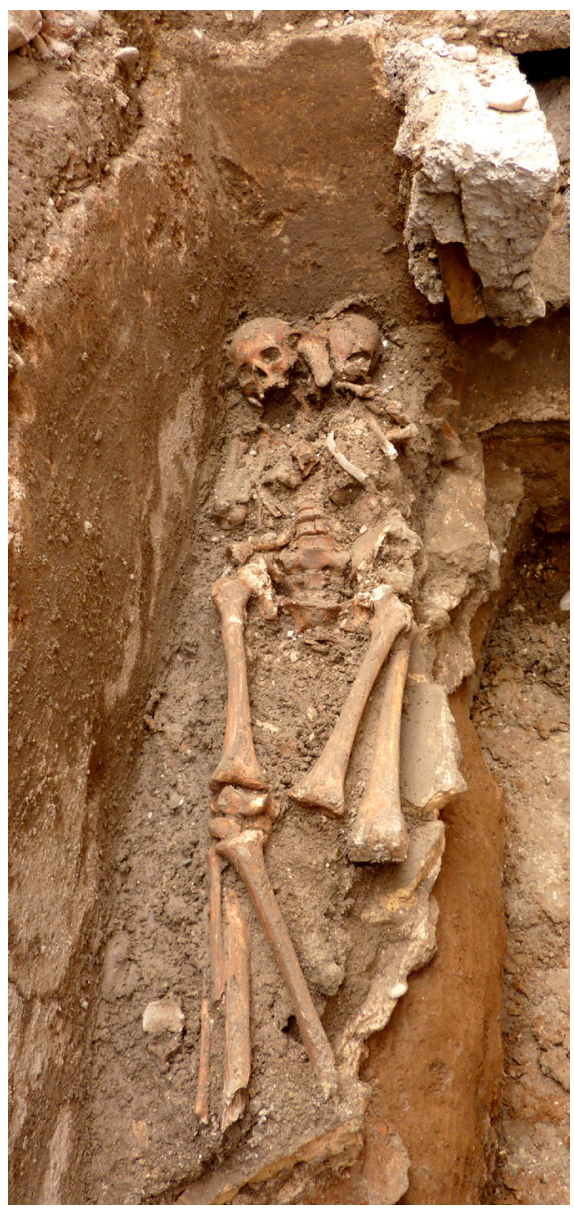

Fig. 6. Double burial inside a tub.

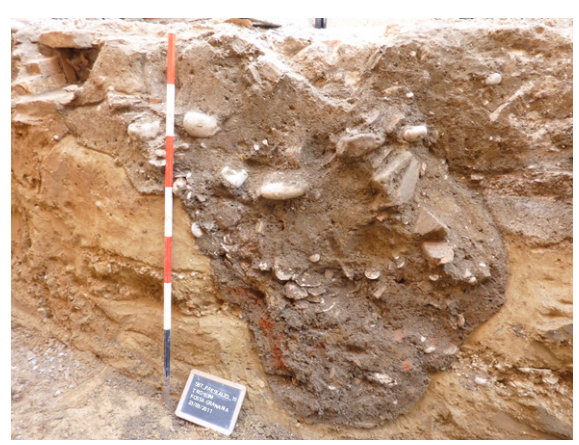

Fig. 7. Section with a grain ditch. the Municipality of Fermo who had acquired the castle in the 13th century. The position and the corner shape of the imposing structure discovered make us think of an angular tower with a polygonal shape similar to the Torrione of Piazza Sacconi, modified many times starting in the 13th century, until its likely demolition around the middle of the 17th century when, due to the increase in population, the residential area was enlarged with the building of Borgo Case Nuove, thus sacrificing the walls that hypothetically ran in correspondence to today's Via Voltattorni. Farther south, in front of Palazzo Piacentini and the Porta Vecchia, a wall was found, the position of which could be evidence of a defensive circuit built previously to the one that even today goes around part of the Upper Town. The finding along Via Rossini of many grain ditches, holes used to conserve wheat, allows us to assume that the area between Porta Vecchia and Piazza Sacconi in the Middle Ages was used for the storage and conservation of perishable goods. These holes, after becoming useless, were then used in the late Middle Ages as "trash bins" as seen in the discovery of 
fragments of vases and oyster shells, proof of the eating habits of the inhabitants of a city that, since antiquity, has had a vocation for maritime life.

The last phase of the town dates to an era closer to us, at least from 1600 onward. The area of Via Rossini and Via Muto, just near the church of San Benedetto Martire, was used as a burial area: more than 30 tombs were found, all in dirt graves (meaning long, narrow graves dug out of the ground), without any particular grave goods.

So we arrive at today. Even if this area is still being studied, the digs carried out here have given us priceless information on the history of the Upper Town of San Benedetto del Tronto, whose roots go back to the height of the Roman era, more than 2000 years ago.

\section{Bibliography}

Adam, Jean-Pierre. 1988. L'arte di costruire presso i Romani-Materiali e tecniche, Milano.

Ambrosi, M. and P. Bronzi. 1995 'Evoluzione geomorfologica delle valli marchigiane, con particolare riferimento alla valle del Tronto", in PICUS, Supplementi IV: 1-15.

Baldelli, Gino and F. Lo Schiavo, eds. 2014. Amore per l'antico: dal Tirreno all'Adriatico, dalla preistoria al Medioevo e oltre: studi di antichità in ricordo di Giuliano De Marinis, Roma.

Bruti Liberati, F. 1845. La prima lettera sopra il castello di San Benedetto del Trono, Ripatransone.

Campagnoli, Paolo and Enrico Giorgi. 2000. 'Alcune considerazioni sulla viabilità romana nelle Marche meridionali, in Journal of Ancient Topography' 10: 105-126.

Catani, Vincenzo, ed. 2004 San Benedetto: il martire e la sua città: nuova documentazione nel $1700^{\circ}$ anniversario del suo martirio (304-2004), San Benedetto del Tronto.

Catani, E. and G. Paci, eds. 2000. La Salaria in età antica, Roma.

2007. La Salaria in età tardoantica e altomedievale, Roma.

Conta. G. 1982. 'Il territorio di Asculum in età romana', in Asculum II, 1. Pisa.

D'Ercole, V., S. Festuccia and A. Stoppiello. 1995. 'Martinsicuro e il territorio a sud del Tronto nella Preistoria', in PICUS, Supplementi IV: 79-109.

De Marinis, Giuliano and Gianfranco Paci. 2000. Atlante dei beni culturali dei territori di Ascoli Piceno e Fermo. Beni Archeologici, Milano.

Giorgi, Enrico. 2000. 'La via consolare salaria e le sue diramazioni nel territorio', in Atlante dei beni culturali dei territori di Ascoli Piceno e Fermo. Beni Archeologici, edited by Giuliano De Marinis and Gianfranco Paci. Milano, 145-153.

. 2006. 'La viabilità delle Marche centro meridionali in età tardo antica e altomedievale', in Atti del XL Convegno di Studi Maceratesi, Macerata, 111-156.

G. Guidotti. 1990. Da San Benedetto in Albula a San Benedetto del Tronto, voll. 1 e 2, Negrar.

Lucentini, Nora. 1995. 'Il territorio di San Benedetto e aree limitrofe nella pre-protostoria', in PICUS, Supplementi IV: 17-48.

2000. 'Prima della Salaria: testimonianze protostoriche', in La Salaria in età antica edited by E. Catani. and G. Paci, Roma, 293-330.

- 2014. 'Tomba bisoma a San Benedetto del Tronto: archeologia o reliquie', in Amore per l'antico: dal Tirreno all'Adriatico, dalla preistoria al Medioevo e oltre: studi di antichità in ricordo di Giuliano De Marinis edited by Gino Baldelli and F. Lo Schiavo, Roma, 917-927.

Mauro, M. 1988. Castelli, rocche, torri, cinte fortificate delle Marche. I castelli dello stato di Fermo, 4, II, Ravenna. 
Pacini, D., ed. 1996. Liber Iurium dell'Episcopato e della Città di Fermo (977-1266): Codice 1030 dell'Archivio Storico Comunale di Fermo, Fermo.

Pappalardo, U. and R. Ciardiello. 2010. Mosaici greci e romani. Tappeti di pietra in età ellenistica e romana, Verona.

Staffa, A. R. 1995. 'Scavi a Martinsicuro: la riscoperta dell'antica Truentum', in PICUS, Supplementi IV: $111-146$

2000. La via Salaria nella bassa valle del Tronto, in La Salaria in età antica edited by E. Catani. and G. Paci, Roma, pp. 417-439.

2007- La via Salaria nella bassa valle del Tronto fra tarda antichità e altomedioevo, in La Salaria in età tardoantica e medievale edited by E. Catani. and G. Paci, Roma, 433-469.

Travaglini, E. 2016. L'antica pieve di S. Benedetto martire, Acquaviva Picena. 